
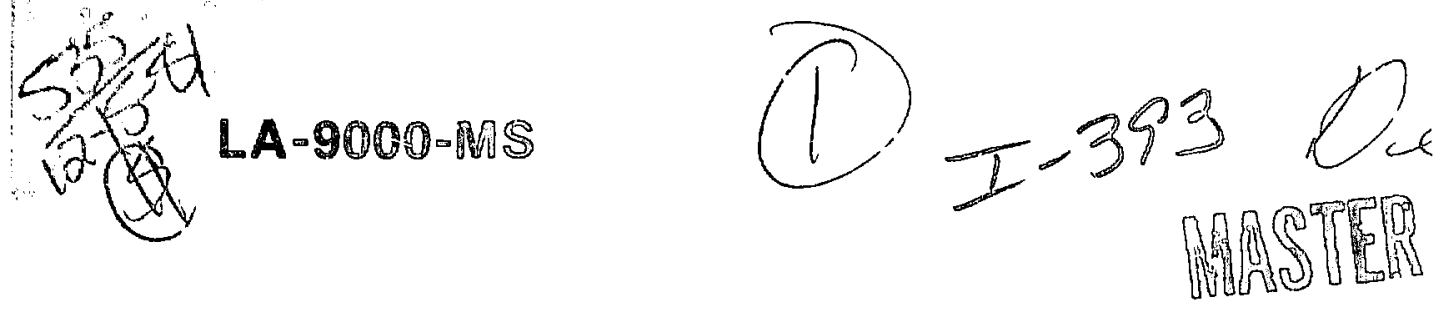

\title{
Further Description of the Petrology of the Topopah Spring Member of the Paintbrush Tuff in Drill Holes UE25A-1 and USW-G1 and of the Lithic-Rich Tuff in USW-G1, Yucca Mountain, Nevada
}


FURTHER DESCRIPTION OF THE PETROLOGY OF THE TOPOPAH SPRING MEMBER OF THE PAINTBRUSH TUFF IN DRILL HOLES UE25A- 1 and USW-GI AND OF THE LITHIC-RICH TUFF IN USW-Gl, YUCCA MOUNTAIN, NEVADA

\section{by}

P. 1. Carroll, F. A. Caporuscio, and D. L. Bish

\section{ABSTRACT}

The Topopah Spring Member of the Paintbrush Tuff and the Lithic-rich tuff are two Tertiary volcanic units that occur in cores from drill holes UE25a-l and USW-GI at Yucca Mountain, Nevada. Recently they have been suggested as possibly suitable for the permanent storage of high-level radioactive waste. This report augments earlier petrologic characterization of these units.

The Topopan Spring Member (approximately $350 \mathrm{~m}$ thick) has two compound cooling units. The upper, thinner unit is densely welded to vitrophyric. The lower unit ranges from nor:.elded to vitrophyric, and its nonwelded base is extensively zeolitized to clinoptilolite and mordenite. Heulandite occurs as fracture fill in the overlying vitrophyric part, but zeolites are absent above that vitrophyre. Here primary devitrification plus vapor-phase crystallization dominate the mineralogy. Vapor-phase effects are especially prominent between the two vitrophyres in both cores and include numerous large lithophysal cavities throughout most of this moderately to densely welded tuff.

The Lithic-rich tuff extends from 1203 to $1506 \mathrm{~m}$ in the USW-Gl drill core. It is nonwelded to partly welded but is ivell indurated due to pervasive intergrowths of authigenic minerals. Thesr phases are analcime, albite, alkali feldspar, sericite, chlorite and quartz. The transition from analcime to secondary albite corresponds to Iijima's zeolite Zone IV boundary, and this boundary appears in USW-Gl at 1326 $m$. However, analcime remains as a prominent phase through most of the Lithic-rich tuff.

Further work is necessary to assess the suitability of either of these horizons for a waste repository. In the Topopah Spring Member, both mechanical and hydrologic properties of the thick lithophysal zone must be studied, as well as the complete sequence of fracture fill. For both units, zeolite and clay mineral stabilities need to be investigated. 


\section{i. INTRODUCTION}

A. Background of Waste-Storage Effort

The possibility of permanent storage of high-level radioactive waste in deep, mined repositories has been and is currently being studied for various rock types in the United States. A major effort of this project is the investigation of tuff at the hevada Test Site (NTS) as a suitable repository medium. A comprehensive exploration program of the thick sequence of tuff underlying Yucca Mountain (located near the southwestern boundary of the NTS) was begun in 1979. Cored holes have been drilled to investigate the stratigraphy, structure, and petrology of the Yucca Mountain area as a part of this program. Los Alamos National Laboratory shares responsibility with the US Geological Survey for characterization of the stratigraphy and petrology of these cores and is especially responsible for identification and description of the core minerals on a microscopic scale.

B. Purpose of this Report

This report is concerned with core samples from two exploration drill holes that were previously studied at Los Alamos: drill holes JE25a-1 (Sykes et al. 1979) and USW-GI (Bish et al. 1981). The latter report will hereafter be referred to as the G1 report. In that report, four units in the USW-G1 core were suggested to have favorable characteristics for a waste repository. The units, listed in order of increasing depth in the drill hole, are: the lower cooling unit of the Topopah Spring Member of the Paintbrush Tuff; the lower cooling urit of the Bullfrog Member of the Crater Flat Tuff; the Tran tuff (informal; Spengler et al., in preparation); and the Lithic-rich tuff (informal; Spengler et al., in preparation). The latter three units were not cored in hole UE25a-1.

Prior to the completion of the Gl report, the Topopah Spring and the Lithic-rich tuff had not been given major consideration as repository horizons, and upon completion of the report, it was thought necessary to provide a description of these units in USW-GI and UE25a-1, which would be comparable in detail to that of the Bullfrog and the Tram tuff in the Gl report. Specifically, the presentation of the Topopah Spring in the UE25a-1 report (Sykes et a). 1979) did not include any detailed x-ray analysis of the clay minerals, iron-titanium oxide average oxidation states were not examined, and alteration/devitrification processes were not interpreted in detail. 
Furthermore, the G1 report described core samples from only the lowermo: portion of the lower cooling unit of the Topopah Spring Member.

The purpose of this report is to provide a reasonably complete petrologic-stratigraphic description of these two units in USW-GI and UE25a-1. To achieve this goal, some inforlation contained in the previous reports is included in this report, but no attempt is made to thoroughly discuss or supplant those descriptions.

C. Methods and Types of Observations

Three instruments were utilized extensively in the petrologic descriptions reported here. A Siemens model D-500 x-ray diffractometer was used for mineral identification in powdered bulk samples and to analyze the clays in a few samples. A polarizing petrographic microscope (reflected and transmitted light) was used to exanine thin sections, enabling description of such features as degree of welding, effects and products of primary devitrification, vapor-phase alteration, secondary alteration, zeolitization, zlay alteration, and opaque mineral average oxidation state, as well as the kinds and abundance of original constituents (shards, pumice fragments, phenocrysts, aroundinass, and lithic fragments). Lastly, a Cameca (Camebax) automated electron microprobe assisted or confirmed the identification of phenocrysts and authigenic phases.

\section{FOREWORD: COMMENTS ON PETROLOGIC OBSERVATIONS}

Explariation of a few of the petrologic observations that are frequently made in this report can best be given here instead of within the presentation of results. Degree of welding is a common and important description of an ash-flow tuff but has only subjective meaning if the terms are not defined. Our working classification of degree of welding is given below (Table I). It is subjective but should give a better inage of the rock we are describing.

At least four processes can profoundly alter the appearance of a tuff in thin section. These are: (1) primary devitrification (alteration of glass to crystalline materials during cooling of the ash-flow sheet); (2) vapor-phase crystallization (growth of crystals promoted or initiated by the presence of a vapor phase pervading the ash-flow sheet during cooling); (3) authigenic recrystallization (here used to denote further recrystallization of crystalline material after cooling and restricted mainly to growth of new silica minerals and alkali feldspars); (4) secondary mineral growth after cooling -- 


\section{TABLE I}

EXPLANATION OF TERMINOLOGY CONCERNING DEGREE OF WELDING IN THIN SECTION

Nonwelded

Slightly welded

Partly welded

Moderately welded

Densely welded

Vitrophyric
-- No deformation of components.

-- Minor shard deformation around phenocrysts.

-- Major shard deformation around phenocrysts; no flow deformation in groundmass.

-- Major shard deformation around phenocrysts; deformation and flow in groundmass.

-- Pronounced shard deformation and alignment.

-- Glassy, all vitric components annealed (perlitic fractures may occur).

chiefly the replacement of glass and other phases by zeolites, clay minerals, opal, etc. Description of the effects of these processes in thin section constitutes a large part of this report.

Following the work of Haggerty (1976), it is possible to recognize exsolution phases in opaque minerals and use them to arrive at empirically determined oxidation states for the opaque minerals. Oxidation states can be determined for both cubic $\left(C_{1}-C_{7}\right)$ and rhombohedral $\left(R_{1}-R_{7}\right)$ exsolution phases, where increasing subscripts indicate increasing oxidation state $(1=$ not oxidized, 7 = completely oxidized). Because oxidation states typically are similar for both the rhombohedral and cubic phases, we use only the $c_{x}$ labels for simplicity. Generally, the oxidation state of the opaque oxides correlates inversely with the degree of welding. The average oxidation states recorded need not necessarily, and most probably do not, record the current oxidation state of the rock in situ.

\section{RESULTS}

A. Topopah Spring Member of Paintbrush Tuff

1. USW-G1 Core. The Topopah Spring Member in the USW-G1 core extends from a depth of 71.6 to $434.3 \mathrm{~m}$. The 61 report thoroughly describes the core from 363 to $434.3 \mathrm{~m}$ (near the basal vitrophyre), but above that interval, only $x$-ray analysis had been performed for earlier reports. Thus, to complete the 
coverage, descriptions of thin sections from six samples above $363 \mathrm{~m}$ are added in this report. Table II summarizes the stratigraphy of the Topopah Spring in the USW-Gl core and lists the depths of samples from which thin sections were made.

\section{TABLE II}

STRATIGRAPHY AND SAMPLING OF THE TOPOPAH SPFING MEMBER IN THE USW-GI CORE

\begin{tabular}{|c|c|}
\hline $\begin{array}{c}\text { Lithologic Groups }{ }^{a} \text { in } \\
\text { the USW-G1 } \\
\text { Topopah Spring Member }\end{array}$ & $\begin{array}{l}\text { Top and Bottom of } \\
\text { Interval in Core } \\
\text { (depths in m) } \\
\end{array}$ \\
\hline $\begin{array}{l}\text { Nonwelded ash-flow } \\
\text { tuff }\end{array}$ & $71.6-82.3$ \\
\hline Vitrophyre & $82.3-85.3$ \\
\hline $\begin{array}{l}\text { Densely welded ash- } \\
\text { flow tuff (quartz- } \\
\text { latitic caprock) }\end{array}$ & $85.3-89.0$ \\
\hline $\begin{array}{l}\text { Densely welded ash- } \\
\text { flow tuff }\end{array}$ & $89.0-139.0$ \\
\hline Ash bed & $139.0-139.3$ \\
\hline $\begin{array}{l}\text { Densely welded ash- } \\
\text { tuff }\end{array}$ & $139.3-392.3$ \\
\hline
\end{tabular}

Depths in Core (m) of Samples Thin-sectioned and Described Either in This or the USW-GI Report

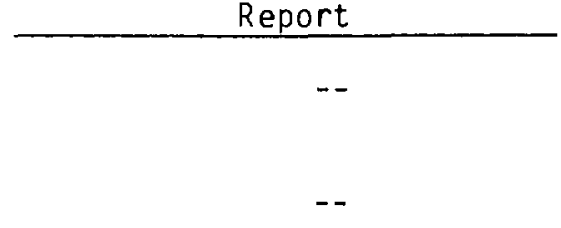

89.0

137.2
$153.6,188.9,220.1,230.7$ Samples above dashed line are new in this report.

Samples below are from USW-GI report. $363,378,392$

\begin{abstract}
Vitrophyre
Moderately welded to nonwelded ash-flow tuff
\end{abstract}

Bedded reworked tuff
$392.3-409.0$

$409.0-427.9$

$427.9-434.3$
394

424

\footnotetext{
a Summarized from the detailed stratigraphy of the US Geological Survey core $\log$ of USW-Gl (Spengler et al., in preparation).
} 
The two thin-section samples above the ash bed at $139 \mathrm{~m}$ are moderately $(137.2 \mathrm{~m})$ and moderately to densely $(89 \mathrm{~m})$ weided and devitrified. Devitrification is evidenced by axiolitic texture in shards and by fibrous aggregates of silica and alkali feldspar occurring as small spherulites throughout pumice fragments and as linings (parallel or radiating) inside pumice borders. Vaporphase crystallization is observed in the growth of tridymite (only optically identified in the higher sample) in void spaces in shards, pumice fragments, and groundmass. Further evidence of vapor-phase crystallization in the sample at $137.2 \mathrm{~m}$ consists of large spherulites in pumice fragments and relatively coarse-grained quartz and alkali feldspar crystals in the centers of shards. The groundmass of both samples contains clay, but in the sample at $89 \mathrm{~m}$, the groundmass is nearly isotropic, suggesting that much is still glass. At 137.2 $\mathrm{m}$, minute crystals (probably quartz and feldspar) are abundant in the groundmass.

Phenocrysts are abundant in both samples, although more so in the upper sample than the lower. The phenocrysts common to these two samples are quartz, plagioclase and alkali feldspars, biotite, magnetite, and minor allanite. The biotite is blackened by opaque acicular crystals parallel and occasionaliy perpendicular to cleavage. The upper sample also has clinopyroxene, and a calcite vein occurs in the sample at $89 \mathrm{~m}$. Lithic fragments are present in both samples.

Below the ash bed there is a section of ash-flow tuff described by Spengler et al. as densely welded, beneath which is the vitrophyre described in the Gl report. These rocks and the underlying moderately welded to (grading downward) nonwelded ash-flow tuff probably represent a single cooling unit. Description of these rocks will be in two parts, the first covering the samples not reported in the Gl report, all of which are above the vitrophyre, and the second reviewing the samples described in that report.

Below the ash bed, the thin-section samples not described in the Gl report are densely welded or (at 153.6 and $230.7 \mathrm{~m}$ ) moderately to densely welded, devitrified, and show the effects of vapor-phase crystallization. Pumice fragments frequently show a border region of spherulitic or parallel aggregates of fibrous silica and feldspar indicative of primary devitrification but are dominated by vapor-phase crystallization. The latter process produces large, occasionally zoned spherulites, and relatively coarse grained quartz, alkali feldspar and tridymite in central regions of relict pumice clasts. 
A minor proportion of the shards in all samples show axiolitic texture, but the more common primary devitrification texture consists of replacement of shards by fibrous radial aggregates of silica and alkali feldspar, either crossing or confined within shard boundaries. Vapor-phase effects in shards are noticeable only in the samples at 153.6 and $230.7 \mathrm{~m}$, and consist of granophyric texture in both samples and tridymite in the deeper sample.

In the groundmass of all the samples in this section, secondary clays and numerous roughly circular pockets filled with tridymite (vapor phase) are found. However, the bulk of the groundmass consists of silica and alkali feldspar, either as a very fine grained crystalline aggregate or as fibrous, brown, radial aggregates. The latter texture is the one described in the preceding paragraph as overprinting shards and in both cases is interpreted as a result of primary devitrification. The texture is first seen in the groundmass at $153.6 \mathrm{~m}$ and becomes progressively more pervasive in both shards and groundmass in the next three samples $(188.7,220.1$, and $230.7 \mathrm{~m})$. In the last sample, the texture obliterates primary textures over large portions of the thin section.

The phenocrysts in these samples are not aburdant and generally consist of plagioclase and alkali feldspars, magnetite, quartz (minor to absent), and minor blackened biotite.

In each of the samples not described in the G1 report (above and below the ash bed), three plagioclase and three potassium-feldspar phenocrysts were analyzed using the microprobe. The only exception to this was one very crystal poor sample (at $220.1 \mathrm{~m}$ ), for which only two crystals of each feldspar were analyzed. The results are summarized in Table III. The typical compositions are sanidine and oligoclase. In comparing this suite of samples, a strong homogeneity is evident in the compositions of each of the two feldspar phenocryst types, and these average compositions compare well with the phenocrysts lower in the Topopah Spring as reported in the Gl report (see Bish et al. 1981$)$.

Above the vitrophyre, the three densely welded samples described in the G1 report are similar to the samples just discussed. All are densely welded, devitrified, and have undergone vapor-phase crystallization. The devitrification spherulites and sprays that had become so prominent in the sample at $230.7 \mathrm{~m}$ are, at 363 and $378 \mathrm{~m}$, smaller and more restricted to bands of flattened shards. The spherulites do cross vitric boundaries but tend to preserve 
ANALYSES BY MICROPROBE OF FELDSPAR PHENOCRYST COMPOSITIONS FOR TOPOPAH SPRING MEMBER SAMPLES NOT DESCRIBED IN THE USW-GI REPORT

\begin{tabular}{|c|c|c|c|c|c|c|}
\hline \multirow[b]{2}{*}{$\begin{array}{l}\text { Sample } \\
\text { Depth } \\
\text { (in m) }\end{array}$} & \multicolumn{3}{|c|}{ Potassium Feldspar } & \multicolumn{3}{|c|}{ Plagioclase Feldspar } \\
\hline & $\% \underset{(A b)}{\operatorname{NaAlSj}} 3^{0} 8$ & 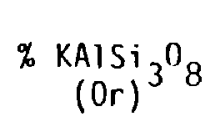 & $\stackrel{\mathrm{CaAl}}{\left.\mathrm{An}_{2}\right)^{\mathrm{Si}}{ }^{0}{ }^{0} 8}$ & $\begin{array}{l}\% \text { NaAlSi } \\
(A b)\end{array}$ & $\begin{array}{c}\% \mathrm{KAISi} 3^{0} 8 \\
(0 r)^{3}\end{array}$ & 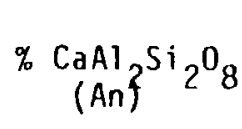 \\
\hline 89 & $\begin{array}{l}48 \\
46 \\
49\end{array}$ & $\begin{array}{l}48 \\
50 \\
48\end{array}$ & $\begin{array}{l}4 \\
4 \\
3\end{array}$ & $\begin{array}{l}76 \\
65 \\
70\end{array}$ & $\begin{array}{l}7 \\
9 \\
7\end{array}$ & $\begin{array}{l}17 \\
26 \\
23\end{array}$ \\
\hline 137 & $\begin{array}{l}52 \\
47 \\
48\end{array}$ & $\begin{array}{l}45 \\
50 \\
49\end{array}$ & $\begin{array}{l}3 \\
3 \\
3\end{array}$ & $\begin{array}{l}74 \\
74 \\
74\end{array}$ & $\begin{array}{l}7 \\
9 \\
12\end{array}$ & $\begin{array}{l}19 \\
17 \\
14\end{array}$ \\
\hline 154 & $\begin{array}{l}56 \\
51 \\
50\end{array}$ & $\begin{array}{l}40 \\
46 \\
47\end{array}$ & $\begin{array}{l}4 \\
3 \\
3\end{array}$ & $\begin{array}{l}78 \\
76 \\
77\end{array}$ & $\begin{array}{l}6 \\
7 \\
7\end{array}$ & $\begin{array}{l}16 \\
17 \\
16\end{array}$ \\
\hline 189 & $\begin{array}{l}41 \\
47 \\
42\end{array}$ & $\begin{array}{l}58 \\
51 \\
57\end{array}$ & $\begin{array}{l}1 \\
2 \\
1\end{array}$ & $\begin{array}{l}64 \\
77 \\
78\end{array}$ & $\begin{array}{l}3 \\
6 \\
6\end{array}$ & $\begin{array}{l}33 \\
17 \\
16\end{array}$ \\
\hline 220 & $\begin{array}{l}41 \\
46\end{array}$ & $\begin{array}{l}58 \\
52\end{array}$ & $\begin{array}{l}1 \\
2\end{array}$ & $\begin{array}{l}77 \\
77\end{array}$ & $\begin{array}{l}8 \\
6\end{array}$ & $\begin{array}{l}15 \\
17\end{array}$ \\
\hline 231 & $\begin{array}{l}46 \\
51 \\
46\end{array}$ & $\begin{array}{l}53 \\
47 \\
53\end{array}$ & $\begin{array}{l}1 \\
2 \\
1\end{array}$ & $\begin{array}{l}79 \\
79 \\
78\end{array}$ & $\begin{array}{l}6 \\
6 \\
5\end{array}$ & $\begin{array}{l}15 \\
15 \\
17\end{array}$ \\
\hline
\end{tabular}


primary textures, in contrast to the sample at $230.7 \mathrm{~m}$. The samples at 363 and $378 \mathrm{~m}$ also have a stronger eutaxitic foliation composed of layers of flattened shards (now fibrous aggregates) and of pumices (now finely crystalline lenses). Vapor-phase effects, such as the presence of lithophysae and large bordering spherulites in puinice fragments, are still observed in these three samples, but post-cooling authigenic recrystallization has begun to alter the rock. The groundmass and interiors of pumice fragments in places are recrystallized to coarser patches of quartz and alkali feldspar and, in the sample at $363 \mathrm{~m}$, some of the circular vugs originally filled with tridymite have recrystallized to polycrystalline quartz. Below $363 \mathrm{~m}$, no sample of the Topopah Spring shows these vugs.

The sample at $392 \mathrm{~m}, 0.3 \mathrm{~m}$ above the vitrophyre, is distinctive in that it is less compacted than the next highe: sample and the shards are devitrified to a distinctive fibrous radial aggregate, reddish-brown in plane light and showing an anomalous bluish extinction under crossed polars. A very similal. rock (sample YM-30) was described by sykes et al. (1979) just above the basal vitrophyre of the Topopah Spring in the UE25a-1 core. They iabeled this aggregate as montmorillonite, but it is more likely that it is an intergrowth of silica and alkali feldspar, with disseminated clays, rutile, and hematite.

The vitrophyre, strongly compacted and densely welded, is composed largely of unaltered glass showing abundant perlitic fractures. The sample below (at $424.3 \mathrm{~m}$ ) is slightly to partly welded and most is unaltered glass, although minor clinoptilolite fills voids in shards and pumice fragments.

The phenocrysts are very similar to those in the samples already discussed - very minor in abundance and composed of two feldspars (compositions are sanidine and oligoclase), opaque minerals, and rare quartz and hiotite. Altered pyroxene phenocrysts are in trace amounts at 424.3 and $378 \mathrm{~m}$. 2. UE25a-1 Core. The Topopah Spring Member was cored in the UE25a-1 drill hole and is described in Sykes et al. (1979).

As an introduction to the thin-section descriptions, the results of $x$-ray diffraction analyses of samples from the UE25a-1 core made for this report (Table IV) will be presented first. X-ray anaiyses are of the same samples of core (22 in number) from which the thin sections described by sykes et al. (1979) were made. These thin sections are further described later in this report. Powder samples were obtained by grinding homogeneous samples of core approximately $1 \mathrm{~cm}^{3}$ in size and were placed in cavity mounts for $x$-ray 
APPROXIMATE MINERAL ABUNDANCES (\% OF SAMPLE) IN TOPOPAH SPRING MEMBER SAMPLES FROM UE25A.-1 DRILL CORE, BY X-RAY OIFFRACTION ANALYSIS

\begin{tabular}{|c|c|c|c|c|c|c|c|c|c|c|c|c|c|}
\hline $\begin{array}{l}\text { Sample } \\
\text { Number }\end{array}$ & $\begin{array}{l}\text { Dep } \\
\text { (m) }\end{array}$ & pth & Smectite & Mica & $\begin{array}{l}\text { Clino- } \\
\text { ptilolite }\end{array}$ & $\begin{array}{l}\text { Morden- } \\
\text { ite }\end{array}$ & Analcime & Quartz & $\begin{array}{l}\text { Cristo- } \\
\text { balite }\end{array}$ & $\begin{array}{l}\text { Alkali } \\
\text { Feldspar }\end{array}$ & Calcite & Glass & Tridymite \\
\hline$Y M-6$ & 84 & 277 & 5 & $5-15$ & - & - & - & - & - & $15-30$ & - & $55-80$ & - \\
\hline YM-7 & 102 & 335 & $<5$ & $5-15$ & - & - & - & - & $5-20$ & $50-70$ & - & - & $5-15$ \\
\hline YM- 8 & 137 & 450 & $5-15$ & - & - & - & - & $5-10$ & $5-20$ & $40-60$ & - & - & - \\
\hline YM-9 & 143 & 469 & $5-15$ & - & - & - & - & $5-10$ & $5-20$ & $40-60$ & - & - & - \\
\hline$Y M-9$ & Clay & Fraction & $10 \pm 10 \%$ il & ite rar & idomly inters & tratified & with mont & orillonit & & & & & \\
\hline$Y M-20$ & 206 & 667 & $5-10$ & - & - & - & - & $40-50$ & $5-15$ & $40-50$ & - & - & - \\
\hline YM-20 & Clay & Fraction & $35 \pm 102$ & lite $r$ & adomly inter & stratified & d with mon & morillon & & & & & \\
\hline$Y M-21$ & 223 & 733 & $5-10$ & $<5$ & - & - & - & $40-50$ & $5-15$ & $40-50$ & - & - & - \\
\hline YM- 17 & 227 & 744 & $5-10$ & $<5$ & - & - & - & $30-40$ & $5-20$ & $40-60$ & - & - & - \\
\hline$Y M-18$ & 255 & 836 & $5-10$ & - & - & - & - & $40-60$ & - & $40-60$ & - & - & - \\
\hline$Y M-22$ & 258 & 848 & $5-10$ & - & - & - & - & $40-60$ & - & $40-60$ & - & - & - \\
\hline$Y M-19$ & 268 & 879 & $5-15$ & $<5$ & - & - & - & $40-60$ & - & $40-60$ & . & - & - \\
\hline$Y M-23$ & 272 & 894 & $5-10$ & - & - & - & - & $40-60$ & - & $40-60$ & - & - & - \\
\hline$Y M-24$ & 286 & 937 & $<5$ & - & - & - & - & $40-60$ & - & $40-60$ & - & - & - \\
\hline$Y M-25$ & 308 & 1012 & $<5$ & .5 & - & - & - & $40-60$ & - & $40-60$ & - & - & - \\
\hline$Y M-26$ & 323 & 1061 & $<5$ & - & $<10$ & - & - & $50-60$ & - & $30-50$ & - & - & - \\
\hline$Y M-27$ & 339 & 1112 & $5-15$ & $5-10$ & - & - & - & $40-60$ & - & $40-60$ & - & - & - \\
\hline$Y M-28$ & 351 & 1153 & $5-15$ & - & - & - & - & $40-60$ & - & $35-55$ & - & - & - \\
\hline$Y M-29$ & 364 & 1195 & $5-10$ & - & - & - & - & $40-60$ & - & $40-60$ & - & - & - \\
\hline$Y M-30$ & 385 & 1264 & $5-10 \ldots$ & .5 & $5 \cdot 10$ & - & - & $40-60$ & $5-15$ & $30-50$ & $\therefore$ & - & - \\
\hline$Y M-31$ & 390 & 1279 & $10-20$ & - & $<10$ & - & - & $<10$ & $10-20$ & $5-15$ & - & $50-80$ & - \\
\hline$Y M-31$ & Clay & Fraction & $20 \pm 10 \%$ & ite $r$ & ndomly inters & stratified & with mont & torilloni & & & & & \\
\hline$r M-32$ & 403 & 1324 & $5-15$ & - & $60-80$ & 55 & - & $5-10$ & - & $5-10$ & - & - & - \\
\hline$Y M-32$ & Clay & Fraction & $25 \pm 10 \%$ & liter & domly inter & stratified & with mont & illonillon & & & & & \\
\hline$Y M-34$ & 414 & 1358 & .5 & - & 6()$-80$ & $5-10$ & - & $5-15$ & - & $5-10$ & - & - & - \\
\hline$Y M-35$ & 421 & 1382 & .5 & - & $50-70$ & $30-50$ & - & - & - & - & - & - & - \\
\hline
\end{tabular}


diffraction. In addition, the clay fraction was separated from four powder samples via sedimentation and centrifugation, and the clays were examined using oriented mounts under a variety of cor itions (air dry, $110^{\circ} \mathrm{C}$, and ethylene-glycol solvated). The results are semiquantitative only, and percentages for cristobalite are unreliable due to complete overlap with the alkali feldspar patterns. Minimum detection limits for most phases range between 1 and $5 \%$. ihe type of smectite present was determined using cavity sample mounts, and the degree of interstratification with illite was determined by comparing the observed x-ray patterns of ethylene-glycol solvated smectite with patt.rns calculated by the method of Reynolds et al. (1970).

Noteworthy aspects of the results are as follows:

(1) There is an upper $(84 \mathrm{~m})$ and a lower $(389 \mathrm{~m})$ vitrophyre.

(2) Quartz first appears at $137 \mathrm{~m}$ and increases in abundance through $385 \mathrm{~m}$.

(3) Tridymite occurs at $102 \mathrm{~m}$.

(4) Clinoptilolite first appears at $323 \mathrm{~m}$ and is a dominant phase below $395 \mathrm{~m}$.

(5) Mordenite first appears at $403 \mathrm{~m}$ and increases downward.

(6) Smectites are present in most sampies but are virtually absent above $90 \mathrm{~m}$ and between $286 \mathrm{~m}$ and $323 \mathrm{~m}$.

(7) Micas, probably biotite, are sporadically distributed and are never dominant components of the tuff. One of the samples (YM-27) yields a broad $10 \AA$ peak suggesting the presence of either illite or an: oxidized/altered biotite.

(8) The clay fractions examined contain montmorillonite randomly interstratified with illite. The clay at $143 \mathrm{~m}$ is almost pure montmorillonite with $10 \pm 10 \%$ illite interstratified. The montmorillonite at $206 \mathrm{~m}$ has substantially more interstratified illite, $35 \pm 10 \%$. The montmorillonites at $390 \mathrm{~m}$ and $403 \mathrm{~m}$ are similar, having $20 \pm 10 \%$ and $25 \pm 10 \%$ interstratified 111 ite, respectively. The degree of interstratification is important because the cation exchange capacity and water loss on heating both decrease with an increase in interstratified illite. The basal spacings of the ethylene-glycol complexes suggest that the layer charges increase with depth. The spacings of the air-dry montmorillonites at 143, 206, and $390 \mathrm{~m}$ suggest that these clays are magnesium and sodium saturated, and the 
montmorillonite at $403 \mathrm{~m}$ appears to be sodium saturated. Future work will be done in an environmental cell on the $x$-ray diffractometer to examine the hydration states of the smectites as a function of temperature and humidity.

The Topopah Spring Member is approximately $331 \mathrm{~m}$ thick in the UE25a-1 drill hole, and the sections indicate at least six discrete portions of two compound ash-flow cooling units. The basal portion (403 to $421 \mathrm{~m}$ ) is nonwelded and heavily zeolitized. Immediately overlying is a basal vitrophyre (385 to $390 \mathrm{~m}$ ), which is in part devitrified. Above the basal vitrophyre is a trick sequence $(255$ to $364 \mathrm{~m})$ of devitrified, densely welded ash-flow tuff that hàs both vapor-phase crystallization and granophyric textures. From 206 to $227 \mathrm{~m}$ is a zone of moderately welded, devitrified ash-flow tuff with moderate vapor-phase crystallization. Finally, at the top of the sequence is a densely welded zone (84 to $137 \mathrm{~m}$ ) with extensive vapor-phase crystallization that correlates to the quartz-latite caprock of Lipman et al. (1966), overlain by a second vitrophyre.

The nonwelded basal section of the Topopah Spring (samples YM-32 to -35) is heavily zeolitized. Clinoptilolite is the predominant zeolite phase in sample YM-32, with only minor mordenite. However, in the progression downward through the nonwelded ash flow, mordenite increases in abundance until it is subequal to clinoptilolite. Another mineralogical change with depth is the distribution of the clays in the samples. In YM-32, most clays are concentrated along shard boundaries and pumice tube walls, with only minor clays elsewhere in the groundmass. The clay content in the groundmass increases steadily with depth. The clay content also increases along pumice tube walls until clays are the dominant textural feature in pumice lapilli of YM-35.

Texturally, these samples resemble the zeolitized portion of the nonwelded flow in the $G 1$ hole. Shards are typically large, undeformed and are completely pseudomorphed by zeolites and clays. Shard borders are rimmed by rutile and clays, which are perpendicular to the boundaries. Inner voids also commonly have terminated clinoptilolite and minor acicular mordenite partially infilling the region. Pumices are pseudomorphed by clinoptilolite, with smectite clays lining tube walls. Groundmass phases in the nonwelded ash flow are fine-grained clinoptilolite, oxides, and clays. As mentioned in the previous paragraph, mordenite becomes more prominent and manifests itself as very small spherulites or acicular sprays. Phenocrysts include quartz, plagioclase, and 
alkali feldspar. Lithic fragments are mostly welded tuff and minor lava clasts.

The basal vitrophyre of the Topopah Spring Member is represented by samples $Y M-30$ and -31 (385 and $390 \mathrm{~m}$, respectively). Sample YM-30 shows primary devitrification in the form of large, sprawling spherulites which crosscut all vitric boundaries. Shards have dark brown cores due to clay concentrations whereas pumice lapilli and shard rims are tan (low clay concentration). Some portions of the pumice are composed of very fine grained granular quartz and alkali feldspar in random patches. Veins in YM-30 are filled with heulandite (Sykes et al. 1979) and montmorillonite. YM-31 is still predominantly glass with rutile and smectite clays aligned parallel to pumice tube walls. Perlitic cracks are abundant in the sample and transgress all boundaries. Veins in this sample are filled by heulandite and/or montmorillonite and rutile. Phenocrysts in both samples of the basal vitrophyre are plagioclase, alkali feldspar, quartz, biotite, and iron-titanium oxides.

Above the vitrophyre is a ihick sequence of densely welded, devitrified ash-flow tuffs. The sample numbers are YM-18, $-19,-22$ to -29 , and sample depths range from 255 to $364 \mathrm{~m}$. All samples show prilary devitrification, vapor-phase crystallization, and granophyric textures resulting in alkali feldspar and silica phases. For the most part, primary devitrification textures are relict or have been overprinted by later authigenic processes. Uoiquitous phenocrysts in this densely welded zone are plagioclase, quartz, and alkali feldspar. Commonly, biotite, magnetite, and hornblende also occur.

Shard morphologies are fairly consistent throughout this densely welded portion of the Topopah Spring Member. Typically the outer Dorder region is composed of fibrous quartz and alkali feldspar intergrowths oriented perpendicular to shard borders. These intergrowths also crosscut shard boundaries and slightly encroach into the groundmass. Growing inward from the fibrous zone, and in some places in optical continuity with the sprays, are terminated vapor-phase crystals (quartz and alkali feldspar) that partially fill the central regions of the shards. In the center of the shards are granophyric patches of large, interlocking quartz and alkali feldspar grains. This sequence is by far the dominant shard morphology in the densely welded tuffs from YM-18 to YM-29. Three other shard morphologies also are present but only in small amounts in samples YM-25 to YM-29. They are (1) axiolitic shards, (2) shards totally dominated by vapor-phase terminal and granular grains of 
quartz and alkali feldspar, and (3) shards composed of fibrous sprays (quartz and alkali feldspar) that lie parallel to outer boundaries. Shards of samples YM-18, $-19,-22$ to -24 , and -28 all have a predominance of vapor phase and granophyric crystallization textures. In samples YM-25 to -27 the vapor-phase and granophyric textures share equal status with types (1) and (2) above. Sample YM-29 has type (3) morphology in addition to the general case.

Pumice morphologies in the thick, densely welded portion all possess common characteristics. First, the border regions are indistinct and composed of granular to fibrous quartz and alkali feldspar intergrowths that cross boundaries and intrude on the groundmass. Next, large spherulites and lithophysae showing numerous growth stages fill most of the central lapilli regions. These spherulites cross and obliterate most original textures. Vapor-phase crystals (quartz and alkali feldspar) partially fill the rest of each pumice fragment, with remaining interstitial areas filled by products of granophyri: crystallization. Samples YM-19, $-24,-28$, and -29 have the largest regions of granophyric crystallization in their pumice lapilli. Less than average amounts of granophyric central regions are evident in samples $Y M-22,-23$, and -27. An additional feature is small pockets of tridymite lined by chalcedony randomly scattered through pumice lapilli. This feature is seen in samples YM-25 to -29. In rare instances, original pumice-tube structures and accompanying small primary devitrification spherulites can be observed.

Groundmass textures can be broken into two distinct groups, the first consisting of dark brown clay-rich regions of spherulitic, fibrous or sheaflike intergrowths of quartz and alkali feldspar with minor oxides. This is the dominant texture in samples $Y M-18,-19,-23$, and -24 . The other groundmass texture is composed of equant, fine- to medium-grained interlocking quartz and alkali feldspar grains. These areas are light tan and clay-poor. This feature predominates in YM-22 but all other samples have varying amounts of the two groundmass textures.

Other features worth mentioning in the densely welded ash-flow zone from 255 to $364 \mathrm{~m}$ are vein $\mathrm{fili}$ and 1 ithophysal cavities. Samples $\mathrm{YM}-22$ and -19 have obvious quartz veins with associated alteration of the wall rock, including all fibrous phases, to a microcrystalline granular aggregate. Samples YM-23, -25, and -26 all have one or more large lithophysal cavities.

Above the thick, densely welded portion of the Topopah Spring is a moderately welded devitrified ash flow at least $51 \mathrm{~m}$ thick. The three samples 
observed in thin section are YM-20, -21, and -17. All three are devitrified and show extensive vapor-piase crystallization and alteration and incipient granophyric crystallization. Shards of YM-17 and -21 are dark brown due to high clay concentrations and have fibrous sheafs of radiating quartz and alkali feldspar oriented parallel to the long dimension of the shards. These sheafs do not cross vitric boundaries. Sample YM-20 also contains this shard morphology in addition to axiolitic shards and shards replaced by granular quartz and alkali feldspar.

Pumice lapilli in the moderately welded portion all have very indistinct borders and an outer region composed of fibrous or granular quartz and alkali feldspar. Small spherulites are also common in the border region. Large sprawling spherulites are common in the central portions of the lapilli with vapor-phase mineralization partially filling interstitial reqions. The vaporphase minerals are quartz and alkali feldspar only in the lowest sample (YM-17). Minor tridymite is present in YM-2l (the next higher sample) in interstitial pumice regions affected by vapor-phase crystallization. The highest moderately welded sample (YM-20) has abundant tridymite along with vapor-phase quartz and alkali feldspar in interstitial punice regions. In addition, most of these vugs are lined with chalcedony.

Many vitric textures are completely obliterated or masked by vapor-phase crystallization and alteration. In all cases the groundmass is very fine grained, granular in appearance, and composed of quartz, alkali feldspar, clays, and oxides. In some regions the groundinass is much larger in grain size and may represent incipient granophyric crystallization. 0ften, in the vicinity of tridymite-filled pockets, all vitric components are changed to the above-mentioned granular texture. Plagioclase is the most common phenocryst in the moderately welded portion of the Topopah Spring Member. Lesser amounts of alkali feldspar, quartz, biotite, and iron-titanium oxides also occur as phenocrysts.

The upper densely welded zone (YM-7 to -9) immediately above the moderate welding zone corresponds to the quartz latite caprock of Lipman et al. (1966). This portion of the Topopah Spring exhibits extreme vapor-phase crystallization and alteration. The effect is so profound that most vitric textures have been masked in the samples. Vapor-phase crystallization manifests itself as large spherulites showing multiple growth stages thai transgress vitric boundaries, pockets of tridymite lined by chalcedony, fine-grained patchy granular 
intergrowths of quartz and alkali feldspar, and granophyric crystallization. When shards are observed in the three samples, they have unusual textures. In YM-9 $(143 \mathrm{~m})$, three dominant shard morphologies are present. In much of this sample, spherulites overprint the groundmass, shards, and pumice. Second, some of the recognizable shards have granophyric textures of quartz and alkali feldspar with tridymite crystals in the core regions. Third, other shards are replaced by fibrous cristobalite and alkali feldspar sheafs oriented parallel to the long dimension of the shards. No shards are discernible in Yiy- 8 , and the only shards observed in YM-7 are comparable to the second textural case stated above.

Pumice lapilli in the upper welded zone have the same features in all three samples. In every case the borders are very indistinct and have been transgressed by large spherulites. The spherulites fill and extend beyond most of the pumice clasts. They are composed of cristobalite and alkali feldspar intergrowths and typically have a mottled appearance. This inotting may be due to the presence of long stringers of clays and oxides oriented parallel to the spherulite fibers. The groundmass of all samples is composed of spherulites or patches of granular cristobalite and feldspar intergrowths. Finally, in all three samples there are abundant ovoid pockets of tridymite crystals. Many pockets are lined by a thin zone of chalcedony. The tridymite ovoids are dispersed throughout the samples but are concentrated particularly in the pumice lapilli.

All three samples have fairly abundant clays. Phenocrysts of this densely welded zone are predominantly alkali feldspar, with minor plagioclase, magnetite and biotite. No quartz phenocrysts were observed.

The highest sample observed (YM-6) in the Topopah Spring Member of the UE25a-1 drill core is a vitrophyre. It is approximately $18 \mathrm{~m}$ above sample YM-7 and may indicate the most densely welded zone of the quartz latite caprock. Vitric components of this sample are glass but are rimmed by clays and oxides. In fact, rutile and hematite, which are disseminated throughout the sample, impart a bright red color to the glass. Phenocrysts are alkali feldspar, plagioclase, biotite, magnetite, spinel(?), and clinopyroxene in YM-6. Orthopyroxene was reported by sykes et al. (1979) in this sample, but only one possible orthopyroxene crystal was observed in thin section, rimmed by clinopyroxene. 
In effect, the Topopah Spring Member of the UE25a-1 drill core is composed of two discrete compound cooling units. The lower cooling unit includes all samples from YM-17 to YM-35 and extends from at least 206 to $422 \mathrm{~m}$. It is complex and comprises (in ascending order) a nonwelded zeolitized interval overlain by a thick vitrophyre, followed by a thick devitrified densely welded interval, and topped by a moderately welded aevitrified interval. Separating this unit from the overlying compound cooling unit is a thin airfall bed (Spengler et al. 1979).

The upper cooling unit consists of samples YM- 6 to $Y M-9$ and includes a densely welded devitrified interval and an overlying vitrophyre. At least 59 $m$ of ash flow make up this cooling unit, which extends from 84 to $143 \mathrm{~m}$ in the drill core.

Possibly, the lower cooling unit was erupted, and while it was still hot and undergoing vapor-phase activity, the upper cooling unit was emplaced. The upper ash flow' was erupted at an extremely high temperature and had the effect of moderately welding the top of the lower unit and the airfall. In essence, the thermal blanketing of the upper unit never allowed the lower unit to have a nonwelded top. Vapor-phase activity was continuing in the lower unit while the hot upper vitrophyre was consolidating. This unusual timing sequence is supported by the following observations.

Vapor-phase crystallization is not present in sample YM-29, which is just above the lower vitrophyre (from which the vapor phase was emanating). Lack of vapor-phase minerals is a common phenomenon directly above a vitrophyre. The densely welded zune in the lower cooling unit shows prominent vapor-phase crystallization, but, in the moderately welded zone above, vapor-phase alteration begins to wane. Above the airfall unit, however, the densely welded portion of the upper cooling unit shows vapor-phase crystallization so prevalent as to nearly obliterate all original textures. Perhaps the overlying upper vitrophyre acted as a blanket to block and concentrate the remaining vapor phase.

3. Oxidation States of Opaque Oxides in USW-G1 Topopah Spring Samples Not Described in the USW-G1 Report, and in UE25a-1 Samples of the Topopah Spring Member. The empirical oxidation states of iron-titanil.m oxides in the USW-G1 and UE25a-1 cores of the Topopah Spring were determined by the use of oxidation exsolution textures (Haggerty 1976). The exsolution phases and textures were determined by reflected-light microscopy and oil-immersion lens 
techniques. As stated previously, generally iron-titanium oxide oxidation states are high $\left(C_{6}-C_{7}\right)$ in nonwelded tuff and low $\left(C_{1}-C_{2}\right)$ in densely welded tuff. For example, in the UE25a-1 core, sample $Y M-35$, a nonwelded tuff, has an average oxidation state of $C_{6}$. Conversely, the opaque minerals of YM-20 (densely welded) show an oxidation state of $C_{1}$.

Two other processes can have a pronounced effect on the oxidation state of the iron-titanium oxides. The first process is vapor-phase crystallization during cooling of the ash flow. Because the vapor phase is often water-rich, it can greatly increase the oxidation state of the opaque minerals. Oxides in the densely welded samples of the Topopah Spring ofter exhibit an average oxidation state higher than would be expected for the degree of welding. The same samples, however, are permeated with vapor-phase crystallization. Close to a vapor-phase pocket, the oxides show maximum oxidation, whereas an appreciable distance away, they are relatively unaltered $\left(C_{2}-C_{3}\right)$. Thus, pioximity to sites of vapor-phase activity can reverse the typical inverce relationship of oxidation state to degree of welding.

The second process is the movement of ground water through fractures in otherwise impermeable tuff. The process can oxidize opaque oxides in densely welded tuff. As an example, $Y M-31$ is a vitrophyre and should be unoxidized but shows maximum oxidation $\left(r_{7}\right)$. Water flowing through the abundant perlitic fractures in the vitrophyre could have oxidized the iron-titarium oxides.

The oxidation states determined for UE25a-1 and USW-Gl samples of the Topopah Spring are given in Table $V$.

4. Topopah Spring Summary. The Topopah Spring Member of the Paintbrush Tuff possesses very similar petrographic characteristics in both the UE25a-1 and USW-GI cores. Both sections are thick, with a total of $363 \mathrm{~m}$ in Gl and $\geq 331 \mathrm{~m}$ in UE25a-1. The Topopah Spring cores from both drill sites are composed of two major cooling units. The upper cooling unit of each consists of a densely welded horizon (quartz-latite caprock) overlain by a vitrophyre. The Gl core has a nonwelded ash flow above this vitrophyre, which was not sampled (Spengler et al., in preparation). Because of an 8-m gap in UE25a-1 samples, the possibility exists that this core also has a nonwelded ash-flow top in its upper cooling unit.

The lower cooling unit in both drill cores contains nonwelded ash-flow tuff, which forms the base. This tuff grades upward into a vitrophyre that is characteristic of both cores. Overlying the vitrophyre in each core is a 


\section{TABLE $V$}

OXIDATION STATES OF FE-TI OXIDES IN THE UE25A-1 AND USW-GI CORES OF THE TOPOPAH SPRING MEMBER

\section{UE25a-1 Samples}

Sample Number, Depth (in $\mathrm{m}$ )

$Y M-6,84$

$Y M-9,143$

$Y M-20,206$

$Y M-22,258$

$Y M-26,323$

$Y M-30,385$

$Y M-31,390$

$Y M-35,421$

Sample Depth

(in $m$ )

89

137

154

189

220

231

Rock Description minor vapor phase

vapor phase

Densely welded, with minor(?)

vapor phase

Moderately to densely welded,

\begin{tabular}{|c|c|c|}
\hline UE25a-1 Samples & $0 \times i$ & $S$ \\
\hline Rock Description & ge & \\
\hline Densely welded ash-flow tuff & $C_{4}$ & \\
\hline Densely welded, with vapor phase & $c_{3}$ & \\
\hline Moderately welded, with vapor phase & $C_{1}$ & \\
\hline Densely welded, with vapor phase & $c_{6}$ & \\
\hline Densely welded, with vapor phase & $C_{5-6}$ & \\
\hline Vitrophyre, with minor vapor phase & $c_{5}$ & \\
\hline Vitrophyre, with minor vapor phase & $c_{7}$ & C \\
\hline Zeolitized, nonwelded ash-flow tuff & $c_{6}$ & \\
\hline
\end{tabular}

USW-G1 Samples Not Described in G1 Report

Oxidation States

Average Range

Moderately to densely welded, with

Moderately welded, with vapor phase

$c_{6}$

$c_{1}-c_{6}$

Moderately to densely welded, with

$c_{6} \quad c_{1}-c_{7}$

Densely welded, with vapor phase

$c_{5-6}$

$\mathrm{C}_{3}-\mathrm{C}_{7}$

$c_{2-3} \quad c_{1}-c_{6}$

with vapor phase

$c_{5} \quad c_{2}-c_{7}$ 
series of densely to moderately welded ash-flow tuffs. Characteristically, the moderately welded tuffs form the top of the lower cooling unit. The moderately welded zone of this lower cooling unit is much less evident and tends toward dense welding in the Gl core. Various possibilities are that the moderately welded zone was stripped off by erosion, or that the Gl locale was sufficiently near the cauldron source to retain a high temperature and allow dense welding throughout.

Devitrification, vapor-phase, and alteration products also correlate to a large degree between the two cores of the Topopah Spring Member. The zeolitized nonwelded tuffs (at the base of the lower cooling unit) and zeolite fracture fill in the lower vitrophyre are primarily clinoptilolite + mordenite and heulandite, respectively, in UE25a-1. In the Gl section, clinoptilolite is the only zeolite observed in the former environment (no mordenite). This minor zeolite phase variation between drill cores can most probably be ascribed to variations in ground-water chemistry. Immediately above the lower vitrophyre, both cores show densely welded devitrified tiffs that are devoid of vapor-phase crystallization. The two sections of Topopah Spring also share the same primary devitrification and vapor-phase crystallization in the dense$1 y$ welded devitrified tuffs (quartz-latite caprock), and an overiying nonaltered vitrophyre.

B. Lithic-Rich Tuff

The Lithic-rich tuff has been described in the Gl report. Further study of the Lithic-rich tuff by additional microprobe and thin-section analyses has not substantially changed the description found in the Gl report of that unit. There were no significant questions with regard to that report concerning the lithic fragments, opaque mineral oxidation states, degree of welding, phenocryst abundance or compositions, etc. Of importance are the type and abundance of low-grade metamorphic alterations, specifically involving the minerals analcime, albite, sericite, chlorite, calcite, and also the alteration of feldspar phenocrysts. Questions also arose about the possibility of undiscovered high-temperature zeolites such as wairakite and laumontite and/or the presence of prehnite-pumpellyite facies minerals as constituents of the Lithic-rich tuff. No such minerals had been reported in the earlier $x$-ray analyses of these samples (Bish et al. 1981), but minor amounts could have escaped detection. 
No significant previously undiscovered authigenic minerals were found within the Lithic-rich tuff, although some phases reported here were not discussed in the Gl report. Thorough study of the thin sections showed several occurrences of unrecognized phases (low-birefringent), but subsequent microprobe analysis showed them to be either alkali feldspar (sanidine or anorthoclase), silica, or nearly pure authigenic potassium feldspar. The first occurs as more or less fragmental-appearing, fibrous, spherulitic or radial aggregates, often with threadlike, branching crystals (rutile?) parallel to the fibrous structure. The second was generally identified as chalcedony in thin section (spherulitic/botryoidal, low birefringence), and the third occurs as tabular, untwinned, clear crystals generaily projecting into void spaces and having a dark gray birefringence. For microprobe results, see Table VI.

\section{TABLE VI}

\section{COMPOSITIONS OF THREE UNKNOWN PHASES IN THE LITHIC-RICH TUFF}

AS DETERMINED BY MICROPROBE ANALYSIS

\begin{tabular}{|c|c|c|c|c|c|c|c|c|}
\hline \multirow[b]{2}{*}{ Oxides } & \multirow[b]{2}{*}{ Radiating } & \multirow[b]{2}{*}{ Fibrous } & \multirow[b]{2}{*}{ Aggregates } & \multicolumn{3}{|c|}{ Unknown Phiases } & \multirow[b]{2}{*}{ Tabular Dark } & \multirow[b]{2}{*}{ ay Crystals } \\
\hline & & & & \multicolumn{3}{|c|}{ Chalcedony(?) } & & \\
\hline $\mathrm{Na}_{2} \mathrm{O}$ & 8.50 & 10.11 & 5.26 & 0.34 & 0.14 & 0.18 & 0.02 & 0.02 \\
\hline $\mathrm{Al}_{2} \mathrm{O}_{3}$ & 18.83 & 19.34 & 18.56 & 7.36 & 5.22 & 5.52 & 17.17 & 17.19 \\
\hline $\mathrm{SiO}_{2}$ & 68.16 & 68.46 & 07.70 & 87.65 & 90.82 & 91.77 & 68.88 & 67.50 \\
\hline $\mathrm{BaO}^{6}$ & 0.00 & 0.02 & 0.13 & 0.02 & 0.11 & 0.03 & 0.09 & 0.00 \\
\hline $\mathrm{Fe} 0$ & 0.37 & 0.57 & 0.66 & 0.22 & 0.00 & 0.78 & 0.00 & 0.01 \\
\hline $\mathrm{K}_{2} \mathrm{O}$ & 3.57 & 1.49 & 8.26 & 5.15 & 3.59 & 2.34 & 15.30 & 15.33 \\
\hline CaO & 0.49 & 0.58 & 0.45 & 0.43 & 0.08 & 0.13 & 0.02 & 0.01 \\
\hline \multirow[t]{3}{*}{ TOTAL } & 99.91 & 100.56 & $\overline{101.02}$ & 101.17 & 99.96 & 100.74 & 101.48 & 100.06 \\
\hline & \multicolumn{8}{|c|}{ Sample Depths (in m) } \\
\hline & 1372 & 1464 & $1614^{b}$ & $1 \overline{1309}$ & 1486 & 1497 & 1486 & 1497 \\
\hline
\end{tabular}

\footnotetext{
a Each list of oxide weight percents is an average of a few analyses for one occurrence of the unknown in the thin section.

bample is from below the Lithic-rich tuff but is the only occurrerice that does not look fragmental.
} 
The Lithic-rich tuff extends from 1203 to $1506 \mathrm{~m}$ in the USW-Gl core and is composed of two units: an upper ash-flow tuff (297 m thick) and a lower bedded tuff $(5.8 \mathrm{~m})$. No samples were taken of the bedded tuff, but twelve samples of the ash flow were examined in thin section. These samples were taken at 1218, 1248, 1282.5, 1309 1323, 1341, 1372.5, 1406, 1432.5, 1464.5, 1486, and $1497 \mathrm{~m}$.

The description in the Gl report of ihe authigenic crystallization in the Lithic-rich tuff lieeus revision only regarding the extent of the alterations. The general picture of alteration is still applicable. Revised descriptions of the Lithic-rich tuff are:

(1) Analcime is a significant pseudomorph of punice, although analcime is altered to varying extents in all samples of the ash flow.

(2) Optically recognizable albite is rare or absent in the samples at. $1372.5,1406,1432.5$, and $1464.5 \mathrm{~m}$. It is obvious at 1309,1323 , and $134 \mathrm{~lm}$, and again at 1486 and $1497 \mathrm{~m}$.

(3) Starting at $134 \mathrm{l} \mathrm{m}$ and continuing down chrough the ash flow, chalcedony is an important phase.

(4) Sericite and chlorite are present in varying amounts throughout the ash flow.

(5) Feldspar phenocrysts can be moderately altered (usually sericitized) in the Lithic-rich tuff and do show overarowths, especially in the deeper samples.

(6) Calcite is not generally a void-fill but occurs as a late-staqe patchy replacement of various components of the rock.

Throughout the Lithic-rich tuff ash-flow sequence, analcime is a common replacement of pumice fragments and the dominant replacement phase of shards. In analcime-pseudomorphed pumice fragments, the most typical alteration is to strands of sericite and/or clay. Generally, within one thin section, pumice fragments vary from completely analcime to strongly sericitized, but alteration is generally minimal at 1282.5, 1309, and $1341 \mathrm{~m}$, and extensive at 1248, 1406, and $1432.5 \mathrm{~m}$. In samples below $1400 \mathrm{~m}$ (roughly), other alteration minerals are present in analcime-pseudomorphed pumice fragments, such as calcite, chalcedony, and albite.

Shards (pseudomorphed by analcime) are much less altered than pumice fragments throughout the ash flow. With the exception of the samples at 1282.5 and $1323 \mathrm{~m}$, analcimitized shards are generally replaced only along their 
boundaries by the same minerals recrystallizing the groundmass-chalcedony or albite. In the two exceptions, some analcimitized shards are recrystallized, either completely or partially, to a mixture of clay and/or sericite with or without silica.

Sericite and chlorite are present in all thin sections of the Lithic-rich tuff in varying amounts. Thin, diffuse, wandering strands of sericite are typically present in pumice fragments pseudomorphed by analcime and are also present in the groundmass. Tiny single crystals of sericite and chlorite are typically finely disseminated through the groundmass. In many samples, sericite mixed with minor chlorite forms veinlets; these are especially thick in the samples at 1218 and $1486 \mathrm{~m}$. These veinlets frequently contain crumpled biotite, sheared or offset along cleavage planes, and a few veinlets might have formed by collapse of pumice fraqments. Chlorite is noticeably concenirated around large opaque oxides in many sections. Because the groundmass ras tiny disseminated opaque minerals in many sections, associated chlorite may be similarly disseminated.

Alteration products can occasionally be seen to develop throughout the groundmass, but often the groundmass is too fine grained to enable identification of either its original or its present constituents. This is certainly true of the samples at 1218 and $1248 \mathrm{~m}$. Clays and opaque oxides (and chlorite and sericite?) are disseminaied throughout, but minerals forming a wicrocrystalline component in the groundmass could not be precisely identified. Through the succeeding samples at 1282.5, 1309, 1323, and $1341 \mathrm{~m}$, the groundmass becones progressively brighter under crossed nicols, changing from gray to gray-white birefringence, and it also becomes coarser grained with depth through the latter three samples. In those same three samples, tabular or lathlike crystals of albite, mostly projecting into voids, are present. First seen at $1309 \mathrm{~m}$, they become larger and more abundant through the next two samples. In the sample at $1341 \mathrm{~m}$, the climax of this albitization trend, plagioclase crystals can finally be seen in the groundmass. Interestingly, in this same sample, when the edges of shards are observed closely, botryoidal forms (probably chalcedony) are seen edging the analcime in addition to crystals more likely to be albite.

In the next three deeper samples (at 1372.5, 1406, and $1432.5 \mathrm{~m}$ ), the groundmass is once again dark and very fine grained, high in clays and oxides, but chalcedony is a significant part of the groundmass. Albite is not 
observed in voids or groundmass, but potassium-feldspar crystals (see Table VI) are present in voids. Chalcedony becomes coarser grained and more abundant (and obvious) in the groundmass of samples from 1432.5 to $1497 \mathrm{~m}$. However, in the last two samples, at 1486 and $1497 \mathrm{~m}$, albite crystals once more fill voids. In the former sample, plagioclase phenocrysts in contact with analcime have obvious overgrowths only into the analcime, into which they project with euhedral teminations. The groundmass, however, is still dominated by chalcedony, seemingly to the exilusion of albite, although the latter mineral may simply be too fine grained to be resolved optically.

The description in the Gl report of feldspar phenocrysts in the Lithicrich tuff suggests greater breakdown of them than actually is the case. Sericitization is the dominant alteration, is generally only moderate, and certainly not uniform. Overgrowths on feldspars occur to a minor extent in samples generally below $1341 \mathrm{~m}$, but, as indicated previously, they achieve their most obvious metarnorphic significance only in the deepest two samples.

Starting at $1282.5 \mathrm{~m}$ and continuing through the ash flow of the Lithicrich tuff, calcite alteration and minor void-fill is present in the thin sections. Generally the calcite occurs in minor, isolated patches but in those patches replaces nearly everything. The calcite becomes erratically more abundant with depth and is most abundant at $1486 \mathrm{~m}$. Generally there seems to be little preference as to alteration locale, but deeper in the core, analcime is frequently replaced by calcite, as are areas of shards and groundinass.

In summary, albite, chlorite, sericite, and quartz are developed throughout the Lithic-rich tuff in the USW-GI core. Since the albite can be demonstrated to have formed from analcime (Bish et al. 1981), Iijima's (1975) Zone III has been surpassed, and the Lithic-rich tuff represents the beginning of Iijima's Zone IV. The mineralogic transitions, however, do not overwhelm the rock. Instead, analcime is a prominent metastable phase as a pseudomorphing mineral of shards and pumice fragments through all the thin sections of the ash flow, and the development of albite is sporadic and may be volumetrically ininor. Only toward the bottom of the ash flow does the transition out of zone III seem to become dominant.

TV. SUMMARY AND CONCLUSIONS

Petrologic descriptions of the Topopah Spring Member of the Paintbrush Tuff and the Lithic-rich tuff have been expanded to be comparable with 
descriptions of other possible radioactive waste isolation repository horizons (at Yucca Mountain, NTS). The Topopah Spring Member was compared between drill cores from UE25a-1 and USW-GI and found to be extremely similar in both cores. Questions that arose in the G1 report concerning the Lithic-rich tuff have been addressed and no major changes have resulted.

clays are found to be ubiquitous throughout all the samples analyzed in this report. Zeolites are present in all Lithic-rich tuff samples and in the nonwelded basal portion and lower vitrophyre fracture fill of the Topopah Spring Member. In addition, the ubiquitous clays and zeolites encountered in the horizons studied all have limited thermal stabilities and are greatly affected by varying water pressures.

In addition, an extremely thick sequence of lithophysal cavities occurs in the moderately to densely welded portions of the Topopah Spring Member. A sequence of lithophysal cavities such as is seen in the Topopah Spring will undoubtedly have direct consequences on physical rock properties. The high incidence of large and small fractures in this zone will affect the possibility of water transport.

Therefore, the following factors that have been encountered must be addressed before any horizon can be accepted as a possible waste repository horizon.

(1) What are the physical and mechanical rock properties of a thick zone containing lithophysal cavities?

(2) How would hydrologic transport be affected by such a lithophysal zone?

(3) Are the abundant fractures of the lithophysal zone filled with stable minerals?

(4) What are the phase stabilities of the zeolites and clays encountered in the Topopah Spring and in the Lithic-rich tuff? How do temperature and water pressure affect phase transformations and/or degradations, and how do these changes correlate to possible volume, permeability, porosity, net water, and mechanical property variations in possible repository horizons? 


\section{REFERENCES}

Bish, D. L., F. A. Caporuscio, J. F. Copp, B. M. Crowe, J. D. Purson, J. R. Smyth, and R. G. Warren, "Preliminary Stratigraphic and Petrologic Characterization of Core Samples from USW-Gl, Yucca Mountain, "evada," Los Alamos National Laboratory report LA-8840-MS (1981).

Haggerty, S. E., "Oxidation of Opaque Mineral Oxides in Basalts," in Oxide Minerals, Min. Soc. Amer. Short Course Notes 3, H6-1 - H6-100 (1976).

Iijima, A., "Effect of Pore Water to Clinoptilolite - Analcime - Albite Reaction Series," J. Fac. Sci. Univ. Tokyo, Sec. II 19, 133-147 (1975).

Lipman, P. W., R. L. Christiansen, and J. T. O'Connor, "A Compositionally Zoned Ash-Flow Sheet in Southern Nevada," US Geol. Surv. Prof. Paper $524-F, F-1-F-47(1966)$.

Reynolds, R. C. and J. Hower, "The Nature of Interlayering in Mixed-Layer Illite-Montmorillonites," Clays and Clay Minerals 18, 25-36 (1970).

Spengler, R. W., F. M. Byers, Jr., and J. B. Warner, "Stratigraphy and Structure of Volcanic Rocks in USW-G1, Yucca Mountain, Nye County, Nevada," US Geol. Surv. Open-File Report (in preparation).

Spengler, R. W., D. C. Muller, and R. B. Livermore, "Preliminary Report on the Geology and Geophysics of Drill hole UE25a-1, Yucca Mountain, Nevada Test Site," US Geol. Surv. Open-File Report 79-1244, 43 p. (1979).

Sykes, M. L., G. H. Heiken, and J. R. Smyth, "Mineralogy and Petrology of Tuff Units from the UE25a-1 Drill Site, Yucca Mountain, Nevada," Los Alamos Scientific Laboratory report LA-8139-MS (1979). 